\title{
Study of wet precipitation and its chemical composition in South of Brazil
}

\author{
ELBA C. TEIXEIRA ${ }^{1}$, DANIELA MIGLIAVACCA ${ }^{2}$, SADI PEREIRA FILHO ${ }^{1}$, \\ ANDRÉA C.M. MACHADO ${ }^{1}$ and JULIANA B. DALLAROSA ${ }^{2}$ \\ ${ }^{1}$ Fundação Estadual de Proteção Ambiental, Rua Carlos Chagas, 55/802 - 90030-020 Porto Alegre, RS, Brasil \\ ${ }^{2}$ Programa de Pós-Graduação em Ecologia, Universidade Federal do Rio Grande do Sul \\ Av. Bento Gonçalves, 9500, 91540-000 Porto Alegre, RS, Brasil \\ Manuscript received on August 17, 2006; accepted for publication on August 29, 2007; \\ presented by ALCIDES N. SIAL
}

\begin{abstract}
The purpose of this study is to analyze the chemical composition of wet precipitation in samples collected at three stations in the Candiota region in the Brazilian state of Rio Grande do Sul (RS). Samples were collected in 2004. Variables analyzed in wet precipitation were $\mathrm{pH}$, conductivity, and concentration of $\mathrm{Cl}^{-}, \mathrm{NO}_{3}^{-}, \mathrm{SO}_{4}^{2-} \mathrm{F}^{-}, \mathrm{Na}^{+}, \mathrm{Ca}^{2+}$, $\mathrm{Mg}^{2+}, \mathrm{K}^{+}, \mathrm{NH}_{4}^{+}, \mathrm{Cu}, \mathrm{Zn}, \mathrm{Fe}, \mathrm{Mn}, \mathrm{Pb}, \mathrm{Ni}, \mathrm{Cd}, \mathrm{Co}$, and $\mathrm{Cr}$. $\mathrm{SO}_{2}$ and $\mathrm{NO}_{2}$ distribution over the time were also evaluated. Results have showed that $\mathrm{pH}<5.6$ are found mostly at Candiota airport $(85 \%)$, followed by Aceguá $(72 \%)$ and Três Lagoas (65\%). Enrichment Factor of the studied ions in wet deposition revealed higher $\mathrm{Ca}^{2+}$ and $\mathrm{SO}_{4}^{2-}$ enrichment in Três Lagoas. Factor Analysis applied to metals and major ions allowed identifying the major sources. While $\mathrm{Cl}^{-}, \mathrm{Na}^{+}, \mathrm{Mg}^{2+}$ are of marine origin, $\mathrm{SO}_{4}^{2-}, \mathrm{NO}_{3}^{-}, \mathrm{NH}_{4}^{+}, \mathrm{F}^{-}$come from anthropogenic sources. Except for Fe and $\mathrm{Mn}$ originating from the soil dust, the metals studied showed to have anthropogenic influence The average $\mathrm{SO}_{2}$ and $\mathrm{NO}_{2}$ concentration, as well as $\mathrm{SO}_{4}^{2-}$ and $\mathrm{NO}_{3}^{-}$in wet precipitation in the Candiota region showed higher concentrations during the warmer months.
\end{abstract}

Key words: wet precipitation, metals, factor analysis.

\section{INTRODUCTION}

The increase in industrialization levels, as well as the growth of urban population, has increased the demand for energy, which in turn caused greater emission of atmospheric pollutants $\left(\mathrm{SO}_{2}, \mathrm{NO}_{\mathrm{x}}\right.$, VOCs and aerosols). Compounds like $\mathrm{SO}_{2}$ and $\mathrm{NO}_{\mathrm{x}}$ are responsible for acid rain in the environment.

It is known that large quantities of pollutants including $\mathrm{SO}_{2}$ are emitted from coal burning and other industrial activities. Many studies confirm that the amount of sulfur released by the emissions of coal combustion process is higher than that of other fossil fuels (e.g., Isobe et al. 2005). The acid deposition resulting from such source processes is currently considered as a potential damage; transformation of such chemicals into more sta-

Correspondence to: Elba Calesso Teixeira E-mail: gerpro.pesquisa@fepam.rs.gov.br ble end products, sulfuric acid, while posing a threat to vegetation and aquatic life in ecologically sensitive areas (Park et al. 2000), can also cause human organ damages (Pandey et al. 2005).

Precipitation is the most effective scavenging factor for the removal of particulate matter and gaseous pollutants dissolved in the atmosphere.

Atmospheric precipitation is slightly acid due to the presence in the air of natural occurrences of sulfur, nitrogen and carbon dioxide. However, an increase in its acidity, as well as alteration in its ionic composition, has been found.

The chemical composition of rain, influenced by natural and anthropogenic sources, is the result of the incorporation of pollutants and particles in the air into the raindrops. Although it is difficult to study experimentally both emission sources, the determination of the 
chemical composition of the rain, as well as the meteorological conditions, may help to understand the cause for its acidification (Sanusi et al. 1996).

Acidification and the ion concentration in the precipitation depend on the constituents of the pollution source, on its physical constitution in the hydrologic system, on the chemical transformation during the cloud development, and on the scavenging below the cloud (Kulshrestha et al. 2003).

The chemical characterization of precipitations continues to be under considerable investigation due to the increase in atmospheric inputs of substances and their effects upon earth, surface water, vegetation, and materials (Bravo et al. 2000).

The subject of acid precipitation and associated environmental problems has received special attention in recent decades and has been submitted to extensive investigation in several countries (Al-Momani et al. 1995).

Some studies have shown the environmental impact of the burning of fossil fuels, like coal, on atmospheric precipitation (Alastuery et al. 1999 and Flues et al. 2002). In the Candiota area, Rio Grande do Sul, Brazil, some research has been done to determine the existence of acid rain originated from the emissions of the biggest coal-fired power station located in Rio Grande do Sul (Migliavacca et al. 2004a, b). These studies measured bulk precipitation and wet precipitation at specific sites, and obtained partial data. The present study complements the study on wet precipitation at other sites under the influence of the power station and at the international border between Brazil and Uruguay, since acid rain possibly brought about by the coal-fired power station located in the area is reason of great concern of the governments of both countries. As a result, the present study aims at identifying physical and chemical parameters $(\mathrm{pH}$, conductivity, major ions and trace elements) in samples of wet precipitation collected in Candiota in order to evaluate the influence of the main anthropogenic sources in the area. $\mathrm{SO}_{2}$ and $\mathrm{NO}_{2}$ distribution over the time were also evaluated in the Candiota region.

\section{STUDY AREA}

The Candiota area, situated in the Southwest of the State of Rio Grande do Sul, Brazil - geographical coordinates $54^{\circ} 10^{\prime} 58^{\prime \prime} / 53^{\circ} 18^{\prime} 35^{\prime \prime}$ West longitude and $31^{\circ} 17^{\prime} 35^{\prime \prime} /$ $31^{\circ} 02^{\prime} 41^{\prime \prime}$ South latitude - about $420 \mathrm{~km}$ from the State capital of Porto Alegre, comprises totally or in part the counties of Aceguá, Bagé, Candiota, Herval, Hulha Negra, Pedras Altas and Pinheiro Machado (Fig. 1).

The biggest coal-fired power plant of Rio Grande do Sul, Usina Termoelétrica Presidente Médici (UPME), is located in Candiota. It is operated by Companhia de Geração Térmica de Energia Elétrica (CGTEE). There are plans to expand its capacity from 350 to $500 \mathrm{MW}$.

In terms of climate, the Candiota area is under the influence of tropical, as well as polar air masses from the sea. The wind blows predominantly from the NE quadrant all year round, although west winds are also present in all directions (Braga et al. 2004).

\section{MATERIALS AND METHODS}

\section{SAMPLING SITES}

The sampling sites for atmospheric precipitation (Aceguá, Candiota Airport and Três Lagoas) were chosen with the help of 1:50.000 cartographic charts, field job and GPS (Global Positioning System). The choice of the sampling sites followed some criteria, according to the ASTM D 5111 Standards (ASTM 1996a). These criteria were: i) predominant wind direction; ii) distance from polluting sources (approximately a radius of $50 \mathrm{~km}$ from UPME); iii) the distance from obstacles that could interfere in sampling (twice the height of obstacles); and iv) logistics (security, access, electric power supply).

\section{Wet PREcipitation SAMPleR}

The sampler for collecting wet precipitation consisted of a metallic protection box and a polyethylene collecting flask of 5-liter capacity, coupled to an acrylic funnel topped by a lid of the same material. The lid opens only during wet precipitation, closing after the precipitation has stopped. It runs on electric power or, in case of power failure, on a $12 \mathrm{~V}$ battery.

\section{SAMPLing PERIOD}

The cleaning of sampling and storing flasks was done with mil-Q water (type I) (conductivity $<2 \mu{\mathrm{S} . \mathrm{cm}^{-1}}^{-1}$ ) (ASTM 1996b), rinsing several times (twice to 3 times) and leaving them stored with this water for at least 24 hours. 


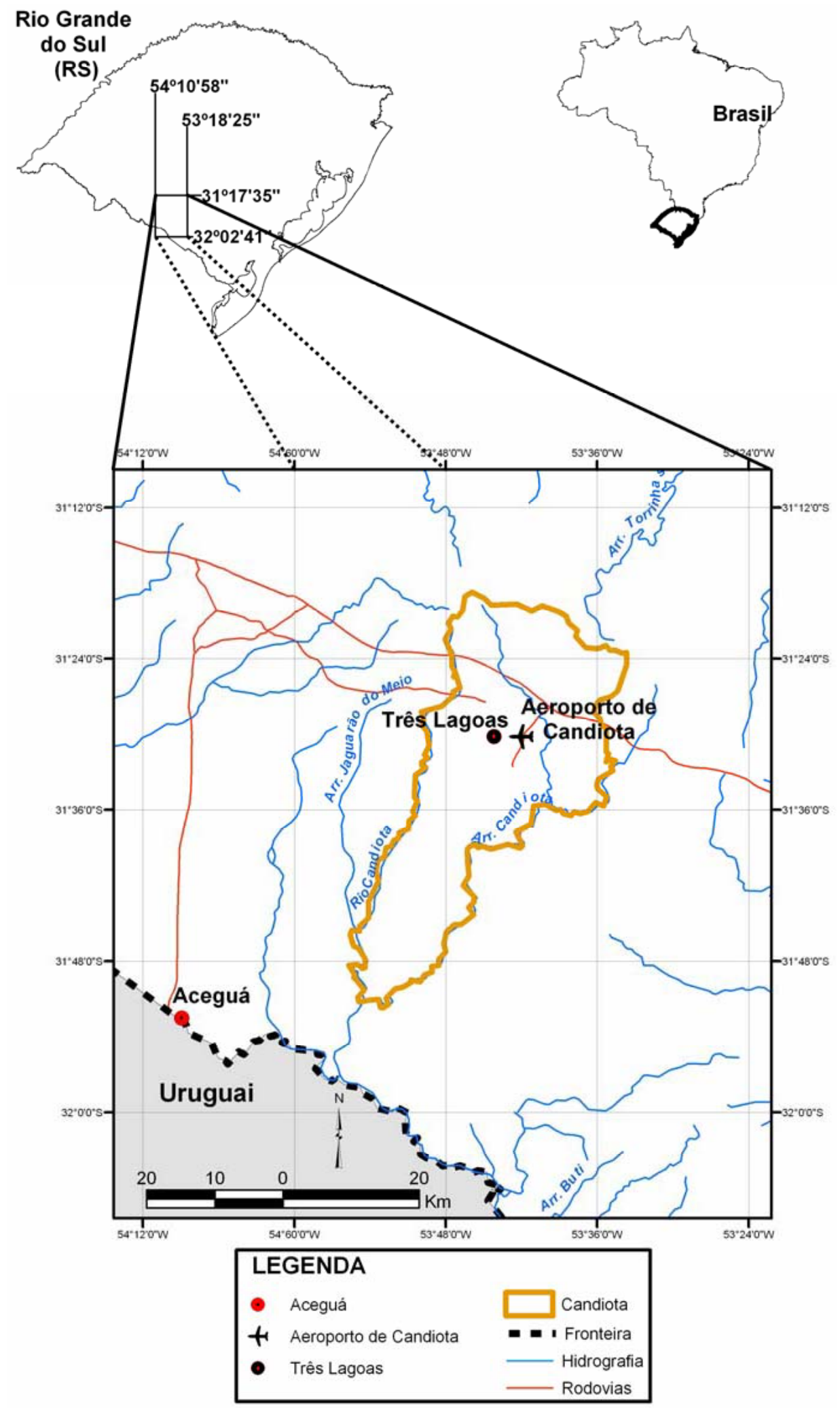

Fig. 1 - Map of the Candiota area. 
Each sample was divided in the amounts required by the specific analytical methods to be performed. Unfiltered samples were used to determine $\mathrm{pH}$, conductivity and alkalinity. Some sample amounts were filtered through a $0.22 \mu \mathrm{m}$ membrane and divided into aliquots. The first aliquot, preserved in chloroform, was used to determine anions and cations. The second, preserved in $\mathrm{HNO}_{3}$ (Merck) superpure at $\mathrm{pH}<2.0$, to determine metals. Both aliquots were stored at $4{ }^{\circ} \mathrm{C}$ until chemically analyzed.

\section{Chemical Analysis}

The unfiltered samples were determined in situ for $\mathrm{pH}$ (Mettler Toledo M 90 potentiometer, precision \pm 0.01 ) and conductivity (Orion Model 105 Plus, readings range 0-100 $\mu$ S.cm ${ }^{-1}$ ).

At the laboratory, the volume of the samples was determined, as well as the $\mathrm{pH}$ and conductivity of unfiltered aliquots. The $\mathrm{pH}$ was determined with a digital pHmeter (Digimed DM-20, precision \pm 0.01 ), and conductivity with an electric conductivimeter (Digimed DM31 ), showing a $1 \%$ precision and range of $0-20 \mu \mathrm{S} \mathrm{cm}^{-1}$.

The major ions were determined through ionic chromatography (Dionex DX 500 with electric conductivity detector). The columns used were AS4A-SC CS12A (Dionex) to analyze anions $\left(\mathrm{Cl}^{-}, \mathrm{NO}_{3}^{-}, \mathrm{SO}_{4}^{2-}\right.$ and $\mathrm{F}^{-}$) and cations $\left(\mathrm{Na}^{+}, \mathrm{Ca}^{2+}, \mathrm{Mg}^{2+}, \mathrm{K}^{+}\right.$and $\mathrm{NH}_{4}^{+}$), respectively. A cationic column $\mathrm{CS} 12 \mathrm{~A}$ with a $\mathrm{H}_{2} \mathrm{SO}_{4}$ $21.7 \mathrm{mmol} \mathrm{L}^{-1}$ solution at a flow of $1.5 \mathrm{~mL} \mathrm{~min}^{-1}$ was used to analyze the cations $\left(\mathrm{Na}^{+}, \mathrm{Ca}^{2+}, \mathrm{Mg}^{2+}\right.$, $\mathrm{K}^{+}$and $\mathrm{NH}_{4}^{+}$). The chromatographic conditions and the optimization of analytical methods are described in the studies of Barrionuevo et al. (2004).

Detection limits were: $0.061 \mu \mathrm{g} / \mathrm{L}$ for $\mathrm{F}^{-}$; $0.051 \mu \mathrm{g} / \mathrm{L}$ for $\mathrm{Cl}^{-} ; 0.28 \mu \mathrm{g} / \mathrm{L}$ for $\mathrm{NO}_{3}^{-} ; \mathrm{SO}_{4}^{2-} ; \mathrm{Na}^{+}$; $0.26 \mu \mathrm{g} / \mathrm{L}$ for $\mathrm{NH}_{4}^{+} ; 0.35 \mu \mathrm{g} / \mathrm{L}$ for $\mathrm{K}^{+} ; 0.21 \mu \mathrm{g} / \mathrm{L}$ for $\mathrm{Mg}^{2+} ; 0.17 \mu \mathrm{g} / \mathrm{L}$ for $\mathrm{Ca}^{2+}$.

To evaluate the ionic balance, the sum of anions and cations was done. The calculation showed higher values for cations $(64.1 \mu \mathrm{eq} / \mathrm{L})$ than for anions $(29.5 \mu \mathrm{eq} / \mathrm{L})$. The deficit in anions is explained by the exclusion of some ionic species, like $\mathrm{HCOO}^{-}, \mathrm{CH}_{3} \mathrm{COO}^{-}$and $\mathrm{HCO}_{3}^{-}$ that were not analyzed in the present work. The two main sources of organic acids in the atmosphere, the oxidized hydrocarbons emitted by the vegetation and the direct emission by industrial sources, both originating organic ions and bicarbonate, could have contributed with significant amounts to the wet precipitation samples of the Candiota area (Mouli et al. 2005).

The analysis of metals $\mathrm{Cu}, \mathrm{Zn}, \mathrm{Fe}, \mathrm{Mn}, \mathrm{Pb}, \mathrm{Ni}, \mathrm{Cd}$, $\mathrm{Co}, \mathrm{Cr}$ was done through the Plasma Emission Spectrometry method, Jobin Yvon, 38 S, coupled to an Ultrasonic Nebulizator. Certified standard solutions (PURE) were used.

Detection limits were: $0.5 \mu \mathrm{g} / \mathrm{L}$ for $\mathrm{Cu}, \mathrm{Ni}, \mathrm{Cd}, \mathrm{Co}$, $\mathrm{Cr}$ and $1.0 \mu \mathrm{g} / \mathrm{L}$ for $\mathrm{Fe}, \mathrm{Mn}, \mathrm{Pb}, \mathrm{Zn}$.

$\mathrm{SO}_{2}$ AND $\mathrm{NO}_{\mathrm{X}}$

Data were collected by $\mathrm{SO}_{2}$ continuous samplers and analyzers (Horiba), model APSA 360, and $\mathrm{NO}_{\mathrm{x}}$ continuous samplers and analyzers, model APNA 360, which are the property of the Companhia de Geração Térmica de Energia Elétrica - CGTEE. The $\mathrm{SO}_{2}$ continuous samplers were installed at three sites in Candiota (Candiota Airport, Três Lagoas, and Dario Lassance), while the $\mathrm{NO}_{\mathrm{x}}$ sampler was installed at one site (Candiota Airport). The data obtained for $\mathrm{SO}_{2}$ and $\mathrm{NO}_{\mathrm{x}}$ are the average for the Candiota region.

\section{ENRICHMENT FACTOR}

The Enrichment Factor (EF) was calculated according to the method suggested by several authors, and described in Keene et al. (1986).

$$
E F=\frac{(X / C)_{\text {precipitation }}}{(X / C)_{\text {reference material }}}
$$

where $X$ is the concentration of the ion of interest and $C$ is the concentration of the reference ion. In the present study, $\mathrm{Na}$ was used as the element of reference.

\section{Statistical TREATMENT}

In order to make the interpretation of data easier, statistical analysis was applied to the chemical variables. It also helped to determine the influence of natural and anthropogenic sources on the atmospheric precipitation of the area under study. The software SPSS for Windows V.9.01 was used with the Factor Analysis technique.

The raw data was used to generate a correlation matrix (Pearson), which in turn was used to determine a new set of synthetic variables (common Factors) based on the interrelations of the original data. These resulting factors are associated to the characteristic roots $>1.0$. 
TABLE I

Chemical composition (average, minimum and maximum) and average concentration pondered by the volume of ions $\left(\mu \mathrm{eq} \mathrm{L}^{-1}\right)$ in the wet precipitation at Candiota region in 2004.

\begin{tabular}{|c|c|c|c|c|c|c|c|c|c|c|c|c|c|}
\hline Station & & $\mathrm{pH}$ & Cond & $\mathrm{H}^{+}$ & $\mathrm{K}^{+}$ & $\mathrm{Ca}^{2+}$ & $\mathrm{Mg}^{2+}$ & $\mathrm{Na}^{+}$ & $\mathrm{NH}_{4}^{+}$ & $\mathrm{SO}_{4}^{2-}$ & $\mathrm{NO}_{3}^{-}$ & $\mathrm{Cl}^{-}$ & $\mathrm{F}^{-}$ \\
\hline \multirow{3}{*}{$\begin{array}{c}\text { Aceguá } \\
n=23\end{array}$} & minimum & 4.91 & 2.60 & 0.26 & 0.73 & 2.42 & 1.03 & 1.99 & 1.91 & 0.25 & 0.25 & 0.87 & 0.003 \\
\hline & maximum & 6.59 & 22.4 & 12.3 & 5.97 & 30.3 & 14.9 & 61.9 & 210 & 33.5 & 7.37 & 73.3 & 24.5 \\
\hline & MPV & & - & & 3.63 & 11.4 & 7.98 & 21.7 & 49.7 & 17.4 & 4.74 & 20.2 & 6.69 \\
\hline \multirow{2}{*}{$\begin{array}{l}\text { Três Lagoas } \\
\qquad n=25\end{array}$} & maximum & 6.34 & 34.5 & 39.8 & 5.82 & 27.2 & 5.32 & 49.8 & 225 & 48.4 & 7.83 & 22.1 & 26.8 \\
\hline & MPV & & - & & 3.88 & 17.7 & 6.95 & 18.5 & 41.6 & 38.5 & 3.81 & 12.8 & 16.1 \\
\hline \multirow{2}{*}{$\begin{array}{l}\text { Airport } \\
n=19\end{array}$} & average & 5.47 & 8.11 & 4.23 & 2.42 & 9.37 & 4.39 & 11.3 & 40.5 & 15.9 & 2.63 & 9.47 & 3.98 \\
\hline & minimum & 4.92 & 1.80 & 0.48 & 0.83 & 3.01 & 1.31 & 2.44 & 2.27 & 1.10 & 0.34 & 0.67 & 0.003 \\
\hline
\end{tabular}

Spearman correlation was applied to the data of chemical elements using log-normal and normal distribution to measure the correlation between the ordinal variables. The values of each variable were ordered from lowest to highest for each selected case.

\section{RESULTS AND DISCUSSION}

MAJOR IONS

Table I shows average, minimum and maximum values of chemical composition and the average concentration pondered by the volume of major ions $\left(\mu\right.$ eq. $\left.\mathrm{L}^{-1}\right)$ in samples of wet precipitation from the sites of Aceguá, Três Lagoas and Airport at Candiota, from January, 2004 to November, 2004.

The average $\mathrm{pH}$ value of the precipitation samples was lower than 5.6 at the three Candiota sites: Aceguá $(\mathrm{pH}=5.32)$, Três Lagoas $(\mathrm{pH}=5.46)$ and Airport $(\mathrm{pH}=$ $5.44)$. This indicates a slightly acid $\mathrm{pH}$ of the precipitation at Candiota area.

The $\mathrm{pH}$ data shows that rain with $\mathrm{pH}$ values below 5.6 occurs in higher percentages at Candiota Airport ( $85 \%$ ), followed by Aceguá (72\%) and Três Lagoas $(65 \%)$.

Figures $2 \mathrm{a}, 2 \mathrm{~b}$, and $2 \mathrm{c}$ show the $\mathrm{pH}$ frequency for the three sites studied. Over $70 \%$ of events showed $\mathrm{pH}$ values below that for acid rain $(\mathrm{pH}<5.6)$, and about $15 \%$ of events were in the range of $\mathrm{pH}=4.5-5.5$. The $\mathrm{pH}$ value found at Aceguá is slightly higher than those determined in previous studies. However, this value is still lower than those found by Zunckel et al. (2003) at the border with Uruguay (Aceguá-Uruguay) between 1999 and 2000. The values found at the time were higher than 5.6.

The average conductivity for the three sites was $7.25(1.80-34.5) \mu \mathrm{S} . c m^{-1}$ and the maximum value for each site was $17.70,34.5$ and $15.60 \mu{\mathrm{S} . \mathrm{cm}^{-1}}^{-1}$, respectively, for Aceguá, Três Lagoas and Airport in Candiota area.

The average values for conductivity were similar to those found in other studies done on the same area, not showing significant variation (Migliavacca et al. 2004a, 2005).

The major ions presence (Table I) indicates that the presence of $\mathrm{Cl}$ in Candiota could be due to sea influence. In fact, this element is in higher concentration than those found in other studies for the Aceguá area Migliavacca et al. 2004b, 2005.

As the $\mathrm{SO}_{4}^{2-}$ concentrations are far more significant than those of $\mathrm{NO}_{3}^{-}$(Table I), $\mathrm{H}_{2} \mathrm{SO}_{4}$ is probably the component responsible for the acidity in the precipitations in the Candiota area.

The higher average percentage of $\mathrm{NH}_{4}^{+}$presented at Candiota Airport can be due to the direct influence of agricultural and cattle raising activities in the region. According to Blume (1992) the high $\mathrm{NH}_{4}^{+}$concentrations found in rainwater might be related to ammonium gas $\left(\mathrm{NH}_{3}\right)$ introduced into the atmosphere mainly by cattle farming by the use of fertilizers $(17 \%)$ and by industrial activities. 


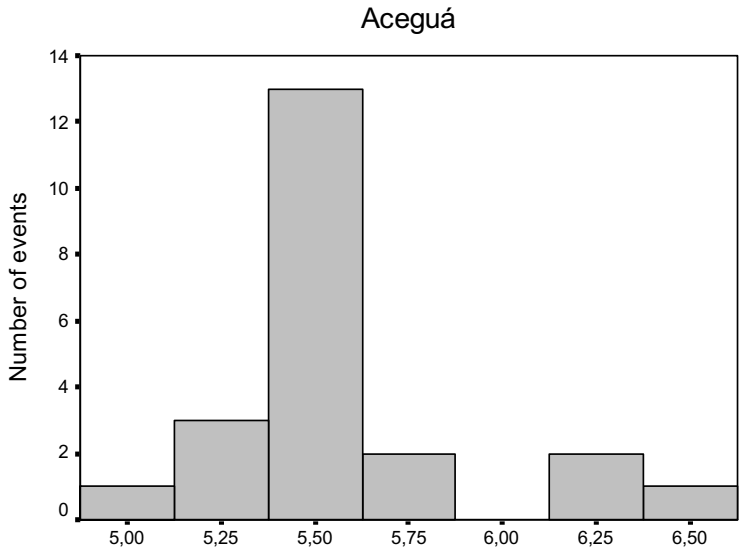

(a)

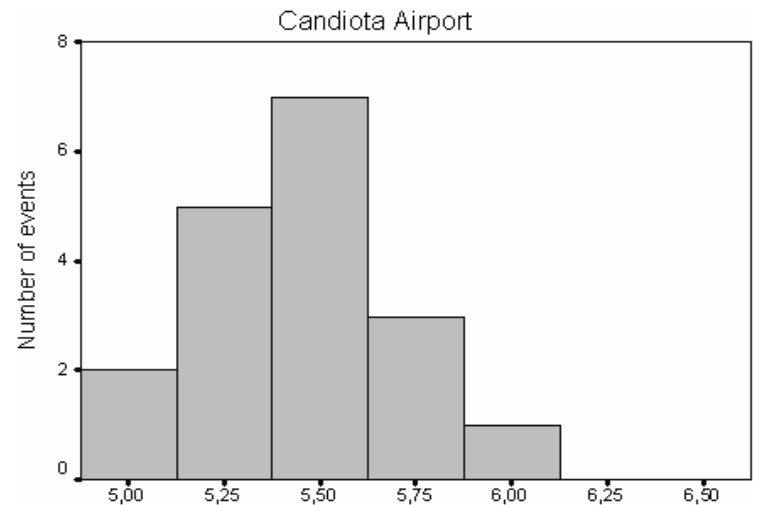

(b)

$\mathrm{pH}$

Três Lagoas

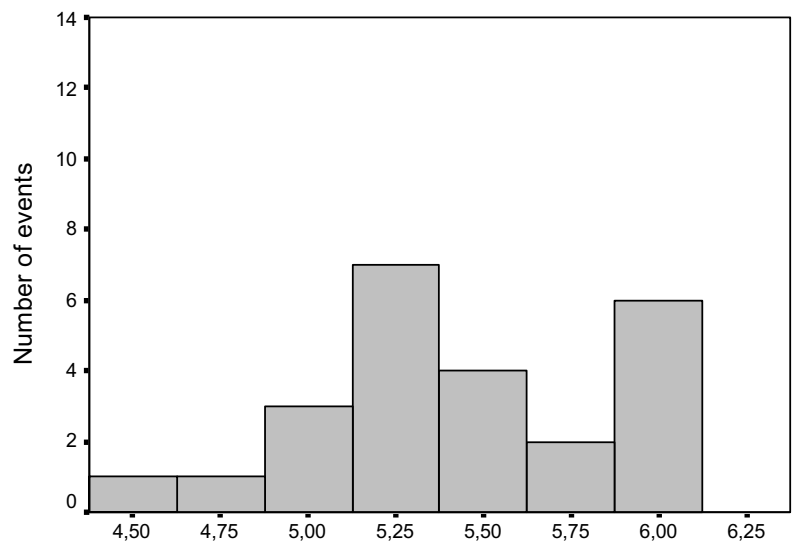

(c)

$\mathrm{pH}$

Fig. 2a-Histogram of $\mathrm{pH}$ values of the wet precipitation - Aceguá site. Fig. $2 \mathrm{~b}-$ Histogram of $\mathrm{pH}$ values of the wet precipitation - Candiota Airport site. Fig. 2c-Histogram of $\mathrm{pH}$ values of the wet precipitation - Três Lagoas site.

The Factor Analysis explained $77 \%$ of total variance (Table II). Factor 1 shows significant values for variables $\mathrm{NO}_{3}^{-}, \mathrm{NH}_{4}^{+}, \mathrm{K}^{+}$. As Candiota is an agricultural area, the use of fertilizers and animal excrements may have contributed to $\mathrm{NH}_{4}^{+}$increase. The high biogenic activity may be the cause for the relatively high load of $\mathrm{NH}_{4}^{+}$ and $\mathrm{K}^{+}$(Migliavacca et al. 2004a, 2005). The presence of ions $\mathrm{NO}_{3}^{-}$e $\mathrm{SO}_{4}^{2-}$ is characteristic of anthropogenic influence, probably the contribution of the power plants.

Ammonia usually occurs in the atmosphere as $\left(\mathrm{NH}_{4}\right)_{2} \mathrm{SO}_{4}$ and $\mathrm{NH}_{4} \mathrm{NO}_{3}$, and thus may be related to $\mathrm{SO}_{4}^{2-}$ and $\mathrm{NO}_{3}^{-}$, suggesting the influence of agricultural activity (Seinfeld and Pandis 1998).

Cape and Leith (2002), in their experiments, found that the quantity of $\mathrm{SO}_{2}$ deposited on the surface of the wet funnel was related to the quantity of $\mathrm{NH}_{3}$ deposited, attributing the fact to the oxidation of dissolved $\mathrm{SO}_{2}$ that reacts with dissolved $\mathrm{SO}_{2}$ producing $\left(\mathrm{NH}_{4}\right)_{2} \mathrm{SO}_{4}$ salts, non volatile during water evaporation.

As there are limestone mines in the area, $\mathrm{Ca}^{2+}$, although showing load $<5$, could be associated to this Factor.

Although $\mathrm{H}_{2} \mathrm{SO}_{4}$ and $\mathrm{HNO}_{3}$ contribute to the acidification of rain water in this area, the presence of $\mathrm{Ca}^{2+}$ results in diminished acidity. This element became evident through the Enrichment Factor.

Through Factor 2, 26\% of the total variance of the raw data is explained. It shows higher loads for $\mathrm{Cl}^{-}$, 
TABLE II

Matrix of factorial loads resulting from varimax rotation, applied to the wet precipitation Candiota region (2004).

\begin{tabular}{c|c|c|c}
\hline \multirow{2}{*}{ Variables } & \multicolumn{3}{|c}{ Factors } \\
\cline { 2 - 4 } & 1 & 2 & 3 \\
\hline $\mathrm{H}^{+}$ & -0.284 & 0.00782 & $\mathbf{0 . 8 7 2}$ \\
\hline $\mathrm{F}^{-}$ & 0.153 & 0.120 & $\mathbf{0 . 7 9 6}$ \\
\hline $\mathrm{Cl}^{-}$ & -0.0264 & $\mathbf{0 . 9 4 9}$ & 0.0424 \\
\hline $\mathrm{NO}_{3}^{-}$ & $\mathbf{0 . 9 0 9}$ & -0.0642 & -0.0479 \\
\hline $\mathrm{SO}_{4}^{2-}$ & 0.641 & 0.0714 & 0.650 \\
\hline $\mathrm{Na}^{+}$ & -0.0286 & $\mathbf{0 . 9 3 3}$ & 0.0247 \\
\hline $\mathrm{NH}_{4}^{+}$ & $\mathbf{0 . 9 0 3}$ & -0.0582 & -0.0342 \\
\hline $\mathrm{K}^{+}$ & $\mathbf{0 . 8 8 2}$ & 0.167 & 0.0465 \\
\hline $\mathrm{Mg}^{2+}$ & 0.299 & $\mathbf{0 . 8 8 2}$ & 0.144 \\
\hline $\mathrm{Ca}^{2+}$ & 0.535 & 0.135 & 0.0462 \\
\hline Extraction (\%) & 33 & 26 & 18 \\
\hline
\end{tabular}

$\mathrm{Na}^{+}$and $\mathrm{Mg}^{+}$, probably indicating sea salt contribution in the area. This contribution could be explained mainly by $\mathrm{Na}^{+}$and $\mathrm{Cl}^{-}$, originating in maritime tropical air and maritime polar air masses that exert influence on the area (Lee et al. 2000, Mello 2001, Lara et al. 2001). Other studies done in Candiota have shown the maritime contribution on this area (Migliavacca et al. 2004a, Braga et al. 2004). This last author demonstrated the influence of the sea breeze of SW direction in relation to the emission source, which is confirmed through the findings of the present study.

Factor 3 showed a variance of $19 \%$ characterized by the ions $\mathrm{SO}_{4}^{2-} \mathrm{H}^{+}$and $\mathrm{F}^{-}$. Fluorides emission at the coal-fired power plant at Candiota were reported in some studies (Fiedler et al. 1990).

Figure 3 a shows the scores distribution at the Três Lagoas site. The association of $\mathrm{H}^{+}, \mathrm{F}^{-}$and $\mathrm{SO}_{4}^{2-}$ in Factor 3 explains the acid $\mathrm{pH}$ values (4.67 and 4.40) occurred at Três Lagoas site on January 21, 2004 and January 24, 2004 , respectively. On these occasions the concentrations of $\mathrm{F}^{-} \mathrm{e} \mathrm{SO}_{4}^{2-}$ were the highest during all the period under study.

At Aceguá site, there is a higher influence of ions of maritime origin. It shows higher scores for Factor 2 ( $\mathrm{Na}, \mathrm{Cl}$ and $\mathrm{Mg}$ ). This result is confirmed by the fact that the highest concentrations for these ions were found at this site. Similar findings were obtained by Migliavacca et al. (2005) and Zunckel et al. 2003) in studies at the same site. As for Factors 1 and 3 (Fig. 3b), no significant variation was obtained; values in the range of $-0,95$ a 3,53, can be considered homogeneous.

At Candiota Airport site, the scores were more homogeneous, values varying from -0,976 a 2,94, (Fig. 3c). The highest value found was for Factor $1\left(\mathrm{NO}_{3}, \mathrm{NH}_{4}, \mathrm{~K}\right.$, $\left.\mathrm{Ca}, \mathrm{SO}_{4}\right)$ on September 21, 2004, when an alkaline $\mathrm{pH}$ (6.32) and a high value for $\mathrm{NH}_{4}$ ions (234 $\left.\mu \mathrm{eq} / \mathrm{L}\right)$ were determined.

\section{ENRICHMENT FACTOR}

Table III shows the average, minimum and maximum values of $\mathrm{EF}$. The highest values of $\mathrm{EF}$ were obtained for $\mathrm{Ca}^{2+}, \mathrm{SO}_{4}^{2-}$ and $\mathrm{K}^{+}$ions at Três Lagoas site. The explanation for this may be the fact that the sampling site is located in the main wind direction (NE-E).

However, $\mathrm{Ca}^{2+}$ shows high values for $\mathrm{EF}$ at the three sites, a strong influence of the limestone mines in the area. The ion $\mathrm{Ca}^{2+}$ could be neutralizing acidity, which could explain the fact that the $\mathrm{pH}$ of the atmospheric precipitation in the area is not as acid as in others. Furthermore, the ion $\mathrm{Ca}^{2+}$ could be an original component from earth or dust (particulate material).

$\mathrm{SO}_{4}^{2-}$ showed EF averages of $9.85 ; 18.64 ; 14.31$ for Aceguá, Três Lagoas and Airport, respectively, in samples of wet precipitation. The coal fired power plant in the area produces $\mathrm{SO}_{2}$; the major atmospheric oxidation of $\mathrm{SO}_{2}$ occurs in the drop, either in the cloud or in the rain, when $\mathrm{SO}_{2}$ dissociates to $\mathrm{HSO}_{3}$. The latter is then quickly oxidized by $\mathrm{H}_{2} \mathrm{O}_{2}$ in the liquid phase, producing reaction of $\mathrm{HO}_{2}$.

Studies on acid rain done in the area and other areas further south near coal fired power plants, showed significant concentrations of sulfate in deposition samples (Migliavacca et al. 2004a, Fiedler et al. 1990).

Just as other ions, $\mathrm{K}^{+}$also showed higher average values for EF at Três Lagoas site (EF: 17.8). At Aceguá and Airport the average values for EF were practically the same (EF: 14.0). The source that could explain the enrichment in $\mathrm{K}^{+}$is earth particles, quite significant in the area. Other studies done in the area and in a nearby State showed significant quantities for $\mathrm{K}^{+}$(Migliavacca et al. 2004b, Zunckel et al. 2003). 


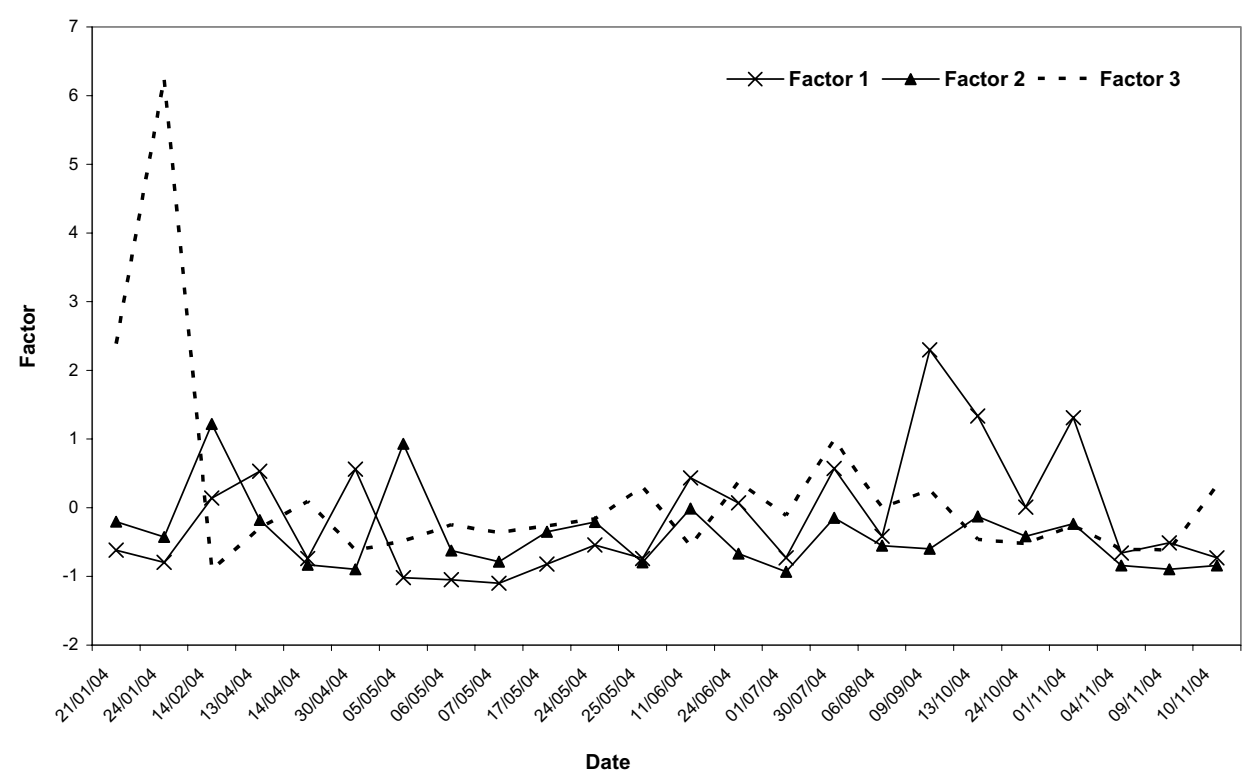

Fig. 3a - Temporal and spatial of Factors 1, 2 e 3 as observed for the ions at Tês Lagoas site for the studied period.

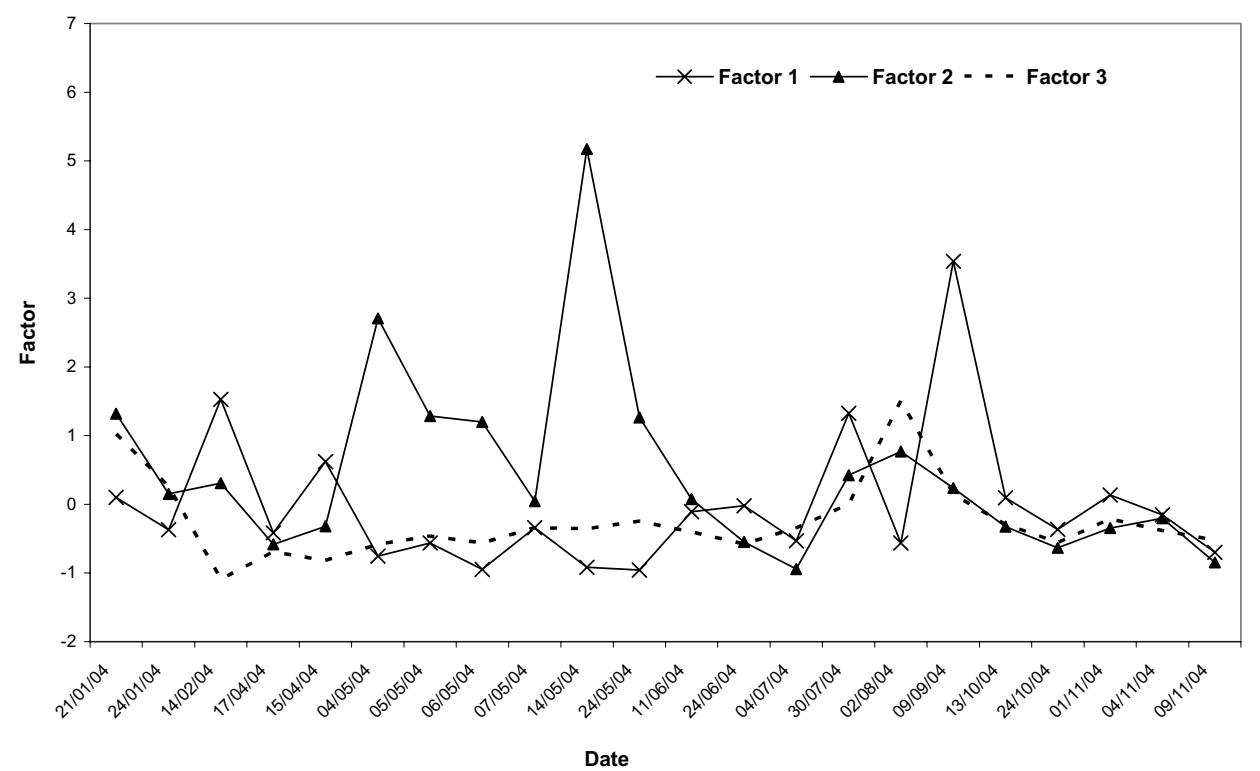

Fig. 3b-Temporal and spatial of Factors 1, 2 e 3 as observed for the ions at Aceguá site for the studied period.

\section{Heavy Metals}

Table IV and Figures $4 \mathrm{a}, \mathrm{b}$ and $\mathrm{c}$ show the average concentration of metals at the three sampling sites from January to December, 2004.

The elements $\mathrm{Ni}, \mathrm{Pb}, \mathrm{Cd}, \mathrm{Co}, \mathrm{Cr}, \mathrm{Cu}, \mathrm{Fe}, \mathrm{Mn}$, and $\mathrm{Zn}$ showed higher concentrations in the wet precipitation samples from May to November. During these months, a higher precipitation level occurred, associated to an acid $\mathrm{pH}(\mathrm{pH}<5.6)$, dissolving the elements present on the ultra fine particles. Elements of anthropogenic and marine origin are more soluble in the precipitation than those derived from the soil dust.

Fe and Mn showed average concentrations of 7.53 e 5.43 ppb in Aceguá (Table IV and Fig. 4a). These concentrations were similar to those reported in other studies done in the same area, although the samples were collected differently (Migliavacca et al. 2004a). These 


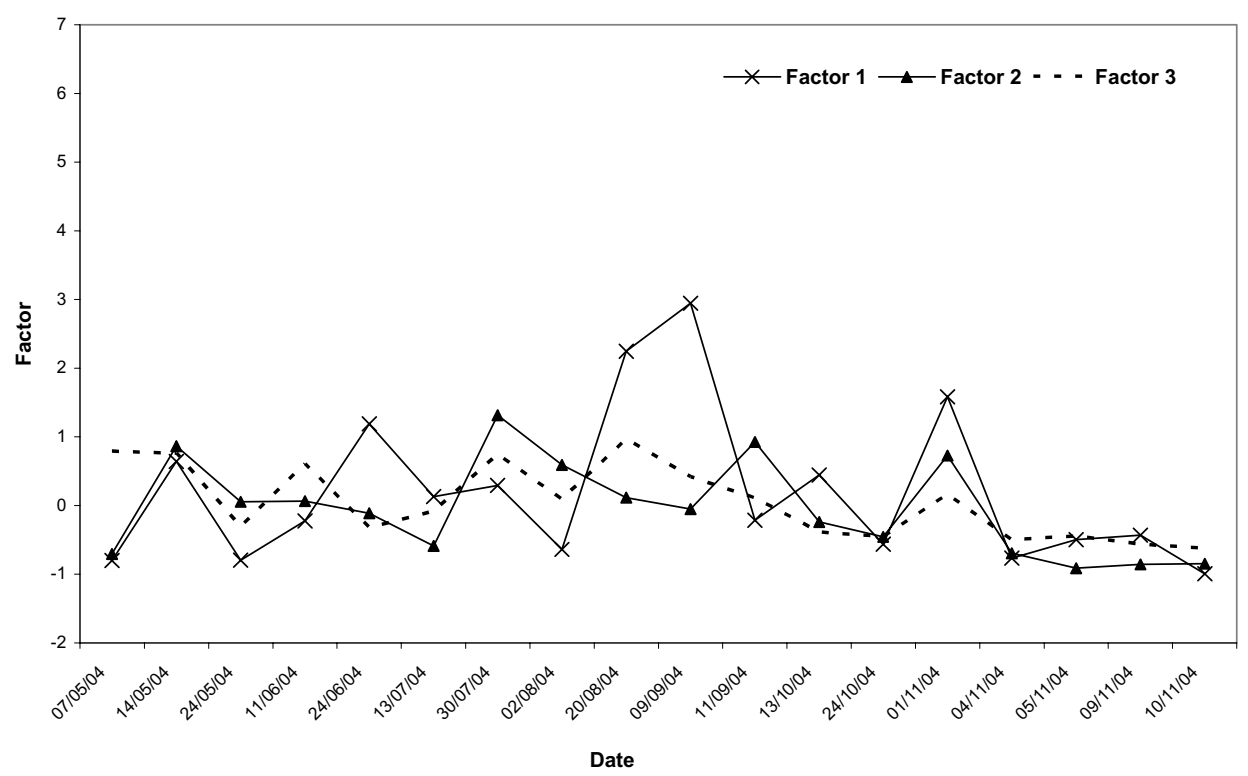

Fig. 3c-Temporal and spatial of Factors 1, 2 e 3 as observed for the ions at Candiota Airport site for the studied period.

TABLE III

Enrichment Factor of wet precipitation samples.

\begin{tabular}{l|c|c|c|c|c|c}
\hline & \multicolumn{2}{|c|}{ Aceguá } & \multicolumn{2}{c|}{ Três Lagoas } & \multicolumn{2}{c}{ Candiota Airport } \\
\hline & Averagand & Minimum-Maximum & Average & Minimum-Maximum & Average & Minimum-Maximum \\
\hline $\mathrm{SO}_{4}^{2-}$ & 10.9 & $(0.146-34.3)$ & 18.64 & $(0.122-53.7)$ & 14.31 & $(3.25-33.7)$ \\
\hline $\mathrm{Cl}^{-}$ & 0.765 & $(0.325-1.22)$ & 0.652 & $(0.0774-1.22)$ & 0.670 & $(0.234-1.09)$ \\
\hline $\mathrm{K}^{+}$ & 13.92 & $(1.67-31.9)$ & 17.81 & $(2.29-63.0)$ & 13.60 & $(3.35-32.0)$ \\
\hline $\mathrm{Ca}^{2+}$ & 26.34 & $(2.07-144)$ & 31.45 & $(3.75-69.8)$ & 26.02 & $(9.63-47.5)$ \\
\hline $\mathrm{Mg}^{2+}$ & 2.36 & $(0.797-7.30)$ & 2.15 & $(0.368-4.67)$ & 2.086 & $(1.06-3.77)$ \\
\hline
\end{tabular}

TABLE IV

Average, minimum and maximum concentrations of metallic elements in wet precipitation samples $\left(\mu \mathbf{g ~ L}^{-1}\right)$ at Candiota region (2004).

\begin{tabular}{c|c|c|c|c|c|c|c|c|c}
\hline \multirow{2}{*}{} & \multicolumn{3}{|c|}{ Aceguá $(\mathrm{n}=18)$} & \multicolumn{3}{c}{ Candiota Airport $(\mathrm{n}=20)$} & \multicolumn{3}{c}{ Três Lagoas $(\mathrm{n}=14)$} \\
\cline { 2 - 11 } & Average & Minimum & Maximum & Average & Minimum & Maximum & Average & Minimum & Maximum \\
\hline $\mathrm{Cu}$ & 0.296 & 0.020 & 1.25 & 0.516 & 0.020 & 1.83 & 0.509 & 0.020 & 3.03 \\
\hline $\mathrm{Fe}$ & 2.35 & 0.005 & 9.19 & 4.16 & 0.005 & 12.8 & 2.92 & 0.005 & 20.7 \\
\hline $\mathrm{Mn}$ & 2.22 & 0.360 & 8.32 & 3.33 & 0.480 & 8.79 & 1.58 & 0.120 & 4.46 \\
\hline $\mathrm{Ni}$ & 0.639 & 0.010 & 2.27 & 0.499 & 0.010 & 1.89 & 0.023 & 0.010 & 0.070 \\
\hline $\mathrm{Pb}$ & 0.131 & 0.050 & 0.570 & 0.286 & 0.050 & 1.17 & 0.153 & 0.050 & 0.900 \\
\hline $\mathrm{Zn}$ & 10.3 & 3.80 & 21.3 & 11.1 & 4.75 & 28.3 & 6.86 & 0.950 & 25.7 \\
\hline $\mathrm{Cd}$ & 0.0636 & 0.005 & 0.240 & 0.177 & 0.005 & 0.830 & 0.011 & 0.005 & 0.030 \\
\hline $\mathrm{Co}$ & 0.199 & 0.005 & 0.50 & 0.194 & 0.005 & 0.620 & 0.072 & 0.005 & 0.310 \\
\hline $\mathrm{Cr}$ & 0.152 & 0.010 & 0.450 & 0.133 & 0.010 & 0.620 & 0.0764 & 0.010 & 0.760 \\
\hline
\end{tabular}




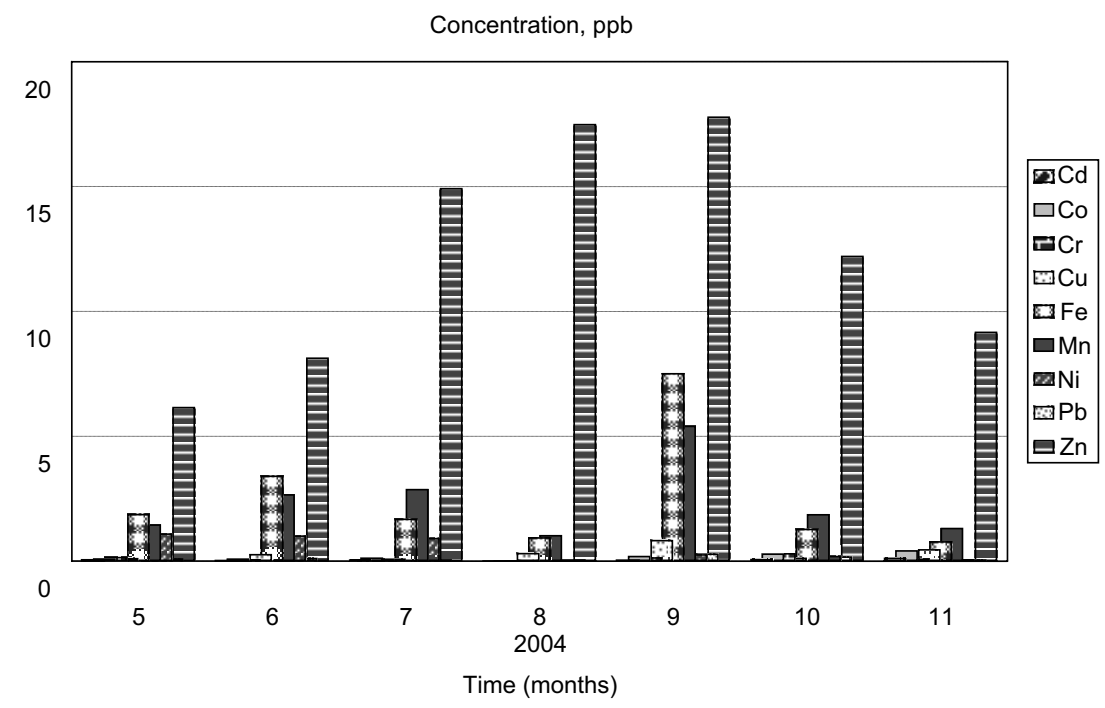

Fig. $4 a$ - Concentration of metallic elements varying with time in wet precipitation at Aceguá - Candiota region (2004).

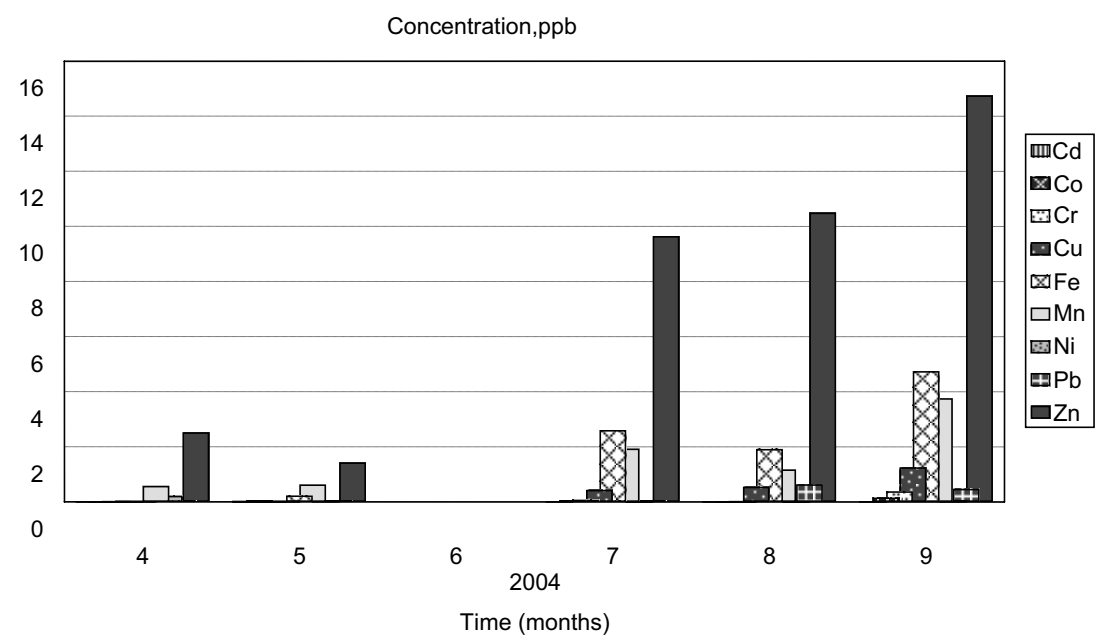

Fig. $4 b$ - Concentration of metallic elements varying with time in wet precipitation at Três Lagoas site - Candiota region (2004).

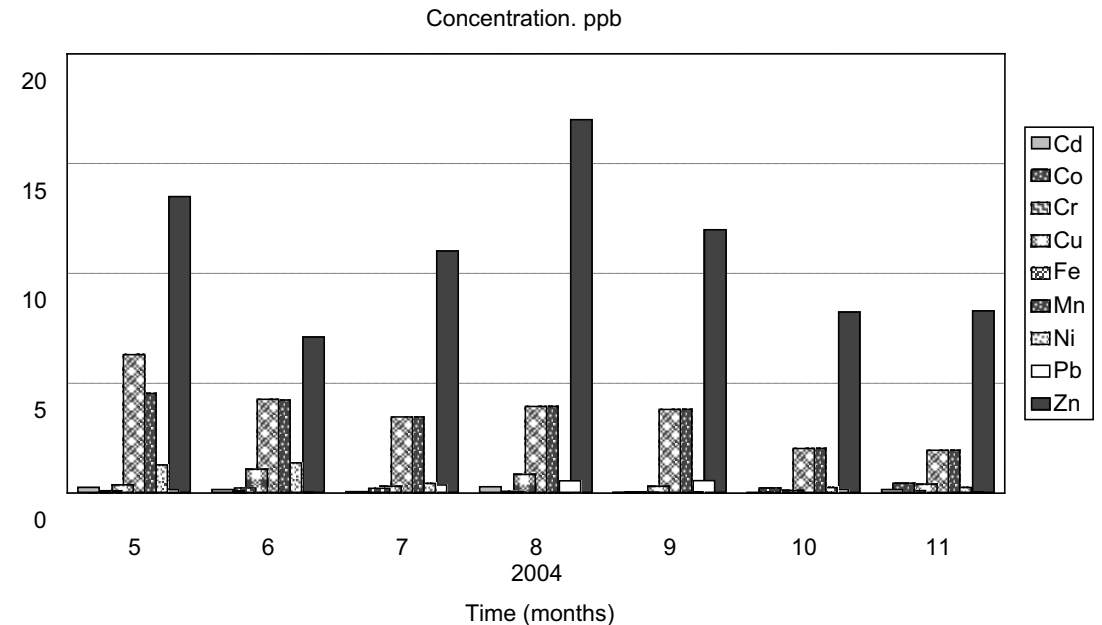

Fig. $4 \mathrm{c}-$ Concentration of metallic elements varying with time in wet precipitation at Candiota Airport site - Candiota region (2004). 
elements and others which have a major crustal component tend to have a lower solubility, although they show a variable characteristic in the precipitation (Spokes and Jickels 1995). However, the anthropogenic metals tend to show a higher solubility under most of the conditions (Spokes and Jickels 1995), as it is dependent on the type of aerosol and on the $\mathrm{pH}$, important variables controlling solubility.

$\mathrm{Zn}$ was the element that showed the highest concentration during the period under study (Figs. 4a, b and c). This data confirm the findings of other studies in Candiota, which report high concentrations of $\mathrm{Zn}$ (Migliavacca et al. 2004a). This indicates strong emission of $\mathrm{Zn}$ from anthropogenic source (coal fired power plant).

Elements $\mathrm{Cu}$ and $\mathrm{Zn}$, removed through precipitation, and their concentrations may depend on the sampling site, as well on collection weather. On rainy days, there was higher solubilization of the elements adsorbed to the fine particles, enhanced also by the acid $\mathrm{pH}$ of the rain $(\mathrm{pH}<5.6)$. At the Aceguá and Três Lagoas sites, the highest concentration of the anthropogenic metals occurred during the rainy period in the month of September.

The Correlation of Spearman was applied to the whole set of data of the chemical elements, synthesizing the whole data into three Factors, representing a total variance of $77 \%$ of raw data (Table V).

TABLE V

Matrix of factorial loads resulting from varimax rotation applied to wet precipitation samples - Candiota region (2004).

\begin{tabular}{c|c|c|c}
\hline \multirow{2}{*}{ Variable } & \multicolumn{3}{|c}{ Component } \\
\cline { 2 - 4 } & 1 & 2 & 3 \\
\hline $\mathrm{Cd}$ & 0.166 & 0.383 & $\mathbf{0 . 6 5 0}$ \\
\hline $\mathrm{Co}$ & 0.129 & 0.210 & $\mathbf{0 . 7 2 1}$ \\
\hline $\mathrm{Cr}$ & 0.317 & $\mathbf{0 . 6 9 7}$ & 0.170 \\
\hline $\mathrm{Cu}$ & $\mathbf{0 . 8 6 6}$ & -0.115 & 0.127 \\
\hline $\mathrm{Fe}$ & $\mathbf{0 . 7 5 9}$ & 0.375 & -0.234 \\
\hline $\mathrm{Mn}$ & $\mathbf{0 . 8 0 9}$ & 0.259 & 0.047 \\
\hline $\mathrm{Ni}$ & -0.098 & $\mathbf{0 . 8 5 9}$ & 0.206 \\
\hline $\mathrm{Pb}$ & 0.393 & 0.336 & -0.516 \\
\hline $\mathrm{Zn}$ & $\mathbf{0 . 8 7 5}$ & 0.017 & 0.176 \\
\hline & & &
\end{tabular}

Factor 1 was represented by the variables $\mathrm{Cu}, \mathrm{Zn}$, $\mathrm{Fe}$ and $\mathrm{Mn}$. The elements $\mathrm{Cu}$ and $\mathrm{Zn}$ are originated in anthropogenic sources and their wet inputs are usually in a dissolved state, especially under $\mathrm{pH}<5$ values (Migon et al. 1996). Fe and Mn are originated from the soil dust, and show low solubility. Fe and Mn are mainly introduced into the atmospheric aqueous phase by influence of particulate re-suspension of soil particles. About $80 \%$ of the total $\mathrm{Fe}$ content is present in an atmospheric particulate sample in the form of various oxides (goethite - $60,8 \%$, hematite $-7,5 \%$, magnetite $-9,8 \%$ ), whereas $10 \%$ were found to be present as ionic $\mathrm{Fe}$ (III) and 10\% were found to be ionic Fe (II) (Hoffmann et al. 1994).

$\mathrm{Cu}$ and $\mathrm{Zn}$ are available into the atmospheric aqueous phase from the coal burning and enriched in the surface of fine particles such as oxides (volatilization - condensation mechanism) and may easily dissolve in contact with the rain, which doesn't happen to Fe and Mn elements (Swaine and Goodarzi 1995, Clarke and Sloss 1992, Davidson and Clarke 1996).

Fe and Mn can be available in soil dust such as hydroxides, oxyhydroxides, silicates, sulfides, etc., which are less soluble than oxides of elements that are commonly found in anthropogenic emission (Kaya and Tuncel 1997).

Studies have shown that in the rainwater $\mathrm{Fe}$ element was particulate, and not soluble in $0.03 \mathrm{M} \mathrm{HNO}_{3}$, implying that Fe-bearing mineral aerosol had not been modified during atmospheric transport, and that very little of the total Fe would be bioavailable (Halstead et al. 2000).

Some authors (Spokes and Jickels 1995), using the critical stability constant, have shown that, while Mn II and Ni II occurred almost entirely as ion hexaqua, $\mathrm{Fe}$ can occur in atmospheric droplets as $\left[\mathrm{Fe}(\mathrm{OH})\left(\mathrm{H}_{2} \mathrm{O}\right)_{5}\right]^{+}$, $\left[\mathrm{Fe}(\mathrm{OH})\left(\mathrm{H}_{2} \mathrm{O}\right)_{4}\right]^{+}$, and $\left[\mathrm{Fe}\left(\mathrm{SO}_{3}\right)\left(\mathrm{H}_{2} \mathrm{O}\right)_{4}\right]^{+}$, the partition of which is a function of $\mathrm{pH}$.

These same authors (Spokes and Jickels 1995) suggest that the anthropogenic elements $\mathrm{Cu}, \mathrm{Pb}$ and $\mathrm{Zn}$ are controlled by the adsorption/desorption process, when rain water supplies sorption sites on the active surface.

Factor 2 is represented by the variables $\mathrm{Cr}$ and $\mathrm{Ni}$. These elements, originating in the coal fired power plant, are adsorbed on the ultra fine particles such as oxides (volatilization - condensation mechanism), probably showing solubility with atmospheric precipitation (Swaine and Goodarzi 1995, Clarke and Sloss 1992, Davidson and Clarke 1996). 
The solubility of anthropogenic elements agrees with that reported in various studies, in which the majority classifies $\mathrm{Zn}$ as the most soluble. Other elements like $\mathrm{Ni}, \mathrm{Cr}, \mathrm{Cu}$ and $\mathrm{Pb}$, however, are reported to show variable solubility, either high or moderate, and authors refer to a variety of influencing conditions, as $\mathrm{pH}$ of the rain and the type of particle these elements are associated to in the atmosphere (Al-Momani et al. 1995, Chester et al. 1993). The solubility of elements is higher in samples of $\mathrm{pH}<5$. However, highly soluble elements are not significantly affected by the $\mathrm{pH}$, because they usually may be soluble in water.

The $\mathrm{pH}$ value of the cloud and of the rain drop can be extremely low. In the cloud occurs the oxidation of $\mathrm{SO}_{2}$ and $\mathrm{NO}_{\mathrm{x}}$, which can be catalyzed by the transition metals. Falconer and Falconer (1980) reported pH values of rain water below 2.2, and suggest that wet aerosols can show values of up to 0.1 (Zhu et al. 1993). That means that the ultimate $\mathrm{pH}$ of the precipitation (between 4 and 6) may not reflect the $\mathrm{pH}$ conditions to which the aerosol is subjected in the atmosphere.

Factor 3 is represented by variables $\mathrm{Cd}$ and $\mathrm{Co}$. These are elements of anthropogenic origin (burning of coal), and are controlled by the adsorption/desorption process dependent on $\mathrm{pH}$.

\section{$\mathrm{SO}_{2} \mathrm{AND} \mathrm{NO}_{2}$}

The area under study is highly influenced by the burning of coal that throws particulate matter in the atmosphere as well as great quantities of acidity generating gases, $\mathrm{SO}_{2}$ and $\mathrm{NO}_{\mathrm{x}}$, which contribute to the development of acid rain. These acidity developing gases are dissolved in the clouds, generating sulfuric and nitric acid.

Figure 5 shows the influence of $\mathrm{SO}_{2}$ and $\mathrm{NO}_{2}$ average concentration in relation to the weather (2004) in Candiota. $\mathrm{SO}_{2}$ and $\mathrm{NO}_{\mathrm{x}}$ concentration peaks have been reported during spring and summer, while autumn and winter months showed intermediate concentrations. The high concentration in summer may be caused by increased power consumption due to higher temperatures during that season.

Concerning $\mathrm{SO}_{4}^{2-}$ and $\mathrm{NO}_{3}^{-}$average concentration in wet precipitation (Fig. 6) the trend is that summer, winter and spring months show peak concentrations. A higher $\mathrm{SO}_{4}^{2-}$ concentration in summer may be partly

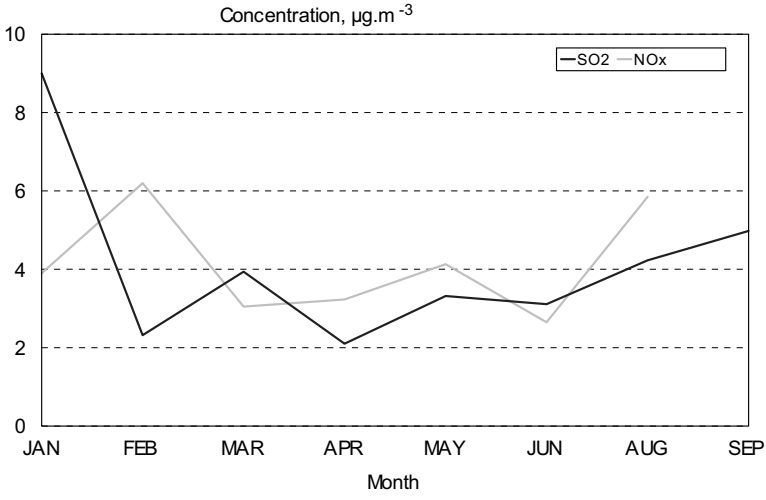

Fig. 5 - Average concentration of $\mathrm{SO}_{2}$ and $\mathrm{NO}_{2}$ in function of time in the Candiota region.

due to higher temperature and incidence of solar radiation, increasing photochemical activity and especially OH levels (Gupta et al. 2003). Despite July and August being winter months, they have shown atypical high temperatures for the period.

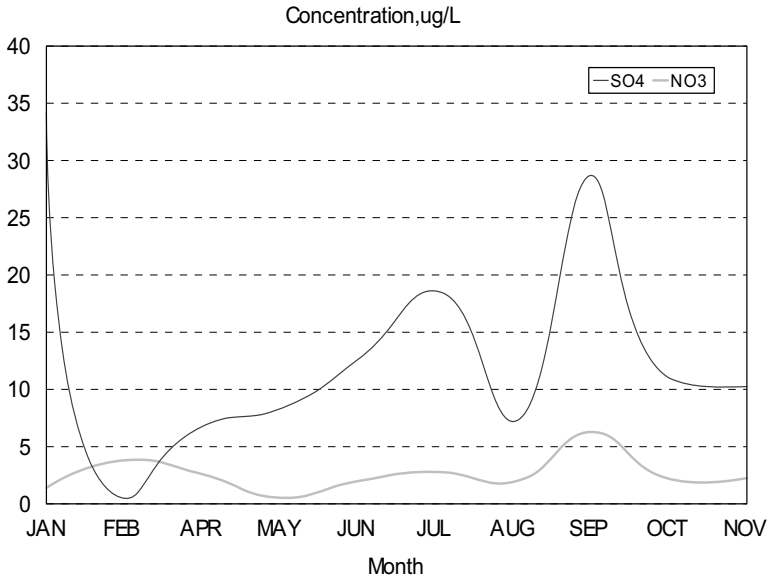

Fig. 6 - Average concentration of $\mathrm{SO}_{4}^{2-}$ and $\mathrm{NO}_{3}^{-}$in the wet precipitation in function of time in the Candiota region.

Although gas data in this study are only partial, $\mathrm{SO}_{2}, \mathrm{SO}_{4}^{2-}$ and $\mathrm{NO}_{2}, \mathrm{NO}_{3}^{-}$tend to show a relation among them. The average $\mathrm{SO}_{2}$ concentration was highest amongst other values reported (Table VI), signaling evidence of acid precipitation. This is confirmed by the $\mathrm{pH}$ of wet precipitation, whose average value is approximatly 5.5 for the Candiota region.

According to some authors (Igarashi et al. 2006), $\mathrm{SO}_{2}$ in the free troposphere is converted to $\mathrm{SO}_{4}^{2-}$ if cloud processes are involved during transport, and some of the 
TABLE VI

Comparison of average concentration of gaseous $\mathrm{SO}_{2} . \mathrm{NO}_{2}\left(\mu \mathrm{g} / \mathrm{m}^{3}\right)$.

\begin{tabular}{c|c|c|c}
\hline Site & $\mathrm{SO}_{2}$ & $\mathrm{NO}_{2}$ & Reference \\
\hline Candiota & 8.91 & 4.33 & Present study \\
\hline Nguyen; Kim & 3.7 & 7.3 & Gupta et al. 2003 \\
\hline Turkey (coastal ) & 2.03 & - & Erduran and Tuncel 2001 \\
\hline
\end{tabular}

sulfate is likely to be removed from the polluted air by precipitation.

$\mathrm{SO}_{2}$ may react with hydroxyl radical in the atmosphere to produce $\mathrm{SO}_{3}^{-}$, which in turn reacts with water vapor to produce sulfuric acid. $\mathrm{SO}_{2}$ may react with hydroxyl radical in the atmosphere to produce $\mathrm{SO}_{3}^{-}$, which in turn reacts with water vapor to produce sulfuric acid.

The oxides of nitrogen, $\mathrm{NO}_{\mathrm{x}}$ mainly emitted in the atmosphere as NO, which is subsequently transformed into $\mathrm{NO}_{2}$ and other nitrogenous species are very important constituents of air pollution. During daytime the most important source of nitric acid is the reaction of $\mathrm{NO}_{2}$ with hydroxyl radical. During the night $\mathrm{NO}_{3}$ free radical is the source of tropospheric $\mathrm{HNO}_{3} . \mathrm{NO}_{3}$ is relatively unimportant during daylight as it is destroyed through its rapid photolysis in sunlight and by its rapid reaction with NO (Stockwell et al. 1997).

Table VI shows $\mathrm{SO}_{2}$ and $\mathrm{NO}_{2}$ data compared with other studies. The data showing a higher $\mathrm{SO}_{2}$ concentration reveals the influence of the coal power station.

\section{CONCLUSIONS}

Results showed that over $70 \%$ of events had $\mathrm{pH}$ values below 5.6 (below the limit for acid rain), and about 15\% of them presented $\mathrm{pH}$ between 4.5 and 5.0. Thus, it is not unreasonable to say that the $\mathrm{pH}$ of the atmospheric precipitation around the area of Candiota is acidified.

The major ions, through the statistical analysis, showed that $\mathrm{NO}_{3}^{-}$(Factor 1 ), $\mathrm{F}^{-}$and $\mathrm{H}^{+}$(Factor 3), and $\mathrm{SO}_{4}^{2-}$ in both Factors (Factors 1 and 3) characterized the anthropogenic influence, probably originating in the coal fired power plant. $\mathrm{Ca}^{2+}$ (Factor 1) is originated, probably, in the limestone mines. Besides, this ion as $\mathrm{NH}_{4}^{+}$and $\mathrm{K}$, respectively, might depend on the use of fertilizer or of soil neutralizers (frequently $\mathrm{CaCO}_{3}$ ), on the soil composition itself, through re-suspension, or on the deposition of the coal plant fly ash. $\mathrm{Cl}^{-}, \mathrm{Na}^{+}$and
$\mathrm{Mg}^{2+}$ are due to marine influence.

The highest EF in the wet precipitation being represented by $\mathrm{Ca}^{2+}$, confirms the strong influence of the limestone mines, earth and dust (particulate matter) on the area.

The wet precipitation tends to easily remove $\mathrm{Ni}$, $\mathrm{Pb}, \mathrm{Cd}, \mathrm{Co}, \mathrm{Cr}, \mathrm{Cr}, \mathrm{Cu}$ and $\mathrm{Zn}$ of anthropogenic origin than $\mathrm{Fe}$ and $\mathrm{Mn}$ elements originated from soil dust. Metals of anthropogenic origin, especially $\mathrm{Zn}$, showed high concentration levels which are controlled by the adsorption/desorption processes and $\mathrm{pH}$. Metals soil dust are mainly associated to minerals and its precipitation removal is essentially $\mathrm{pH}$ controlled.

Candiota area shows problems with acid precipitation and the contribution of ions sulfate and metals in the precipitation. This tendency will probably get worse with the implantation of the Candiota III power plant. More ions will be emitted and metals will be adsorbed to ultra fine particulate matter that escapes the control equipment.

The average $\mathrm{SO}_{2}$ and $\mathrm{NO}_{2}$ concentration, as well as $\mathrm{SO}_{4}^{2-}$ and $\mathrm{NO}_{3}^{-}$in wet precipitation in the Candiota region showed higher concentrations during the warmer months. Nevertheless, gases should be studied for a longer period to better assess distribution of $\mathrm{SO}_{2}$ and $\mathrm{NO}_{2}$ over the time in relation to ions $\left(\mathrm{SO}_{4}^{2-}\right.$ and $\left.\mathrm{NO}_{3}^{-}\right)$ in wet precipitation.

\section{ACKNOWLEDGMENTS}

We thank Conselho Nacional de Desenvolvimento Científico e Tecnológico (CNPq) and Fundação de Amparo à Pesquisa do Estado do Rio Grande do Sul (FAPERGS) for the financial support. We also thank the Sampling Service of Fundação Estadual de Proteção Ambiental (FEPAM) and Companhia de Geração Térmica de Energia Elétrica (CGTEE) for their contribution to the study. 


\section{RESUMO}

O objetivo deste estudo é analisar a composição química da precipitação úmida em amostras coletadas em três estações na região de Candiota no Estado do Rio Grande do Sul (RS) Brasil. Amostras foram coletadas em 2004. Variáveis analisadas na precipitação úmida foram $\mathrm{pH}$, condutividade e concentração de $\mathrm{Cl}^{-}, \mathrm{NO}_{3}^{-}, \mathrm{SO}_{4}^{2-} \mathrm{F}^{-}, \mathrm{Na}^{+}, \mathrm{Ca}^{2+}, \mathrm{Mg}^{2+}, \mathrm{K}^{+}, \mathrm{NH}_{4}^{+}, \mathrm{Cu}$, $\mathrm{Zn}, \mathrm{Fe}, \mathrm{Mn}, \mathrm{Pb}, \mathrm{Ni}, \mathrm{Cd}$, Co e Cr. Distribuição no tempo de $\mathrm{SO}_{2}$ e $\mathrm{NO}_{2}$ também foi avaliada. Resultados mostraram que $\mathrm{pH}<$ 5,6 são encontrados em sua maioria no aeroporto de Candiota (85\%), seguidos pelo Aceguá (72\%) e Três Lagoas (65\%). Fator de Enriquecimento dos íons estudados na deposição úmida revelou maior enriquecimento de $\mathrm{Ca}^{2+} \mathrm{e} \mathrm{SO}_{4}^{2}$ em Três Lagoas. Análise Fatorial aplicada aos metais e íons maiores permitiu identificação de fontes maiores. Enquanto $\mathrm{Cl}^{-}, \mathrm{Na}^{+}, \mathrm{Mg}^{2+}$ são de origem marinha, $\mathrm{SO}_{4}^{2-}, \mathrm{NO}_{3}^{-}, \mathrm{NH}_{4}^{+}, \mathrm{F}^{-}$são provenientes de fontes antropogênicas. Exceto $\mathrm{Fe}$ e Mn originários de poeira do solo, os metais estudados mostraram ter influência antropogênica. A média da concentração de $\mathrm{SO}_{2}$ e $\mathrm{NO}_{2}$, bem como $\mathrm{SO}_{4}^{2-}$ e $\mathrm{NO}_{3}^{-}$na precipitação úmida na região de Candiota mostrou maiores concentrações durante os meses mais quentes.

Palavras-chave: precipitação úmida, metais, análise fatorial.

\section{REFERENCES}

Alastuery A, Querol X, Aura Chaves CR, CarraTALA A AND LOPEZ-SOLER A. 1999. Bulk deposition in rural area located around a large coal-fired power station, Northeast Spain. Environ Pollut 106: 359-367.

Al-Momani IF, Ataman OY, Anwari AM, Tuncel S, Köse C And Tuncel G. 1995. Chemical composition of precipitation near an industrial area at Izmir, Turkey. Atmos Environ 29: 1131-1143.

ASTM. 1996a. Standard guide for choosing locations and sampling methods to monitor atmospheric deposition at non-urban locations: D 5111, West Conshohocken, PA.

ASTM. 1996b. Standard guide for preparation of material used for the collection and preservation of atmospheric wet deposition: D 5012. West Conshohocken, PA 11: 387-391.

Barrionuevo S, Nascimento RSH, Machado ACM AND PIRES M. 2004. Caracterização química da precipitação atmosférica por cromatografia iônica. In: TEIXEIRA EC AND PIREs M (Eds), Estudos ambientais em Candiota: carvão e seus impactos. $1^{\text {a }}$ ed., FINEP/PADCT/ CIAMB/FAPERGS/FEPAM, Porto Alegre, RS, Brasil, p. 193-200.
Blume HP. 1992. Handbuch des Bodenschutzes. Ecomed, Munchen, p. 247-248.

Braga CF, Teixeira EC, Yonema ML and Dias JF. 2004. Study of the elemental composition of aerosols in the Candiota region of Brazil using the PIXE technique. Nuclear Instruments and Methods in Physics Res B 225: 561-571.

Bravo HA, SAAVEdra MIR, SÁnchez PA, TORRes RJ AND GRANADA LMM. 2000. Chemical composition of precipitation in a Mexican Maya region. Atmos Environ 34: 1197-1204.

CAPE JN AND LeITH ID. 2002. The contribution of dry deposited ammonia and sulphur dioxide to the composition of precipitation from continuously open gauges. Atmos Environ 36: 5983-5992.

Chester R, Murphy KJ, Lin FJ, Berry AS, BradSHOW GF AND CORCORAN PA. 1993. Factors controlling the solubilities of trace elements from non-marine aerosols deposited to the sea surface by the dry deposition mode. Mar Chem 42: 107-126.

Clarke LB and Sloss LL. 1992. Trace elements-emissions from coal combustion and gasification, IEACR/49. IEA Coal Research, London, $111 \mathrm{p}$.

DAVIDSON RM AND ClARKE LB. 1996. Trace elements in coal. Kluwer Academic Publishers, 59 p.

ERdurAn MS AND TUNCEL SG. 2001. Gaseous and particulate air pollutants in the Northeastern Mediterranean Coast. Sci Total Enviro 281: 205-215.

FALCONER RE AND FALCONER PDJ. 1980. Determination of cloud water acidity at a mountain observatory in the Adirondack Mountains of New York State. J Geophys Res 85: 7465-7470.

Fiedler HD, Martins AF AND Solari J. 1990. Meio ambiente e complexos carboeletriocs: o Cado de Candiota, Ciência Hoje 12 (68): 38-45.

Flues M, Hamma P, Lemes MJL, Dantas ESK and FORNARO A. 2002. Evaluation of the rainwater acidity of a rural region due to a coal-fired power plant in Brazil. Atmos Environ 36: 2397-2404.

Gupta A, KUMAR R, KUMARI KM AND SRIVASTAVA SS. 2003. Measurements of $\mathrm{NO}_{2}, \mathrm{HNO}_{3}, \mathrm{NH}_{3}$ and $\mathrm{SO}_{2}$ and related particles matter at a rural site in Rampur, India. Atmos Environ 37: 4837-4846.

Halstead MJR, Cunninghame RG and Hunter KA. 2000. Wet deposition of trace metals to a remote site in Fiordland, New Zealand. Atmos Environ 34: 665-676. 
HoFFMANN P, SinNer P, DEDIK AN, KARANDASHEV VK, MAlyshev AA, Weber S AND ORTNer HM. 1994. Iron in atmospheric aqueous and particulate samples. Fresenius J Anal Chem 350: 34-37.

IGARASHI Y, YoSUKe SAWA Y, YOSHIOKA K, AKAHASHI H, MATSUEdA H AND DoKIYA Y. 2006. Seasonal variations in $\mathrm{SO}_{2}$ plume transport over Japan:Observations at the summit of Mt. Fuji from winter to summer. Atmos Environ 40: 7018-7033.

Isobe Y, YAmada K, WAN Q, SAKamoto K, UChiYAma I, Mizoguchi T AND ZHOU Y. 2005. Measurements of indoor sulfur dioxide emission from coal biomass briquetties. Water, Air, Soil Pollut 163: 341-353.

KAYA G AND TUNCEL G. 1997. Trace element and major ion composition of wet and dry deposition in Ankara. Turkey. Atmos Environ 31: 3985-3998.

KeEne WC, Pszenny AAP, Galloway JN and HaWLEY ME. 1986. Sea-salt corrections and interpretation of constituent rations in marine precipitation. J Geophys Res 91: 6647-6658.

Kulshrestha UC, Monika Kulshrestha MJ, SeKar R, SASTRY GSR AND VAIRAMANi M. 2003. Chemical characteristics of rainwater at an urban site of south central India. Atmos Environ 37: 3019-3026.

LARA LBLS, ARTAXo P, MARTINELli LA, Victoria RL, Camargo PB, Krusche A, Ayers GP, Ferraz esB AND BAllester MV. 2001. Chemical composition of rainwater and anthropogenic influences in the Piracicaba river basin, Southeast Brazil. Atmos Environ 35: 49374945.

Lee BK, Hong SH And LeE DS. 2000. Chemical composition of precipitation and wet deposition of major ions on the Korean peninsula. Atmos Environ 34: 563-575.

Mello WZ. 2001. Precipitation chemistry in the coast of the Metropolitan Region of Rio de Janeiro, Brazil. Environ Pollut 114: 235-242.

Migliavacca D, Teixeira EC, Pires M and Fachel J. 2004a. Study of chemical elements in atmospheric precipitation in South Brazil. Atmos Environ 38: 1641-1656.

Migliavacca D, TeiXeira EC, Pires M, FaChel J, Machado ACM and Porto F. 2004b. Em Estudos ambientais em Candiota: carvão e seus impactos. TeIXeIra EC AND PIREs M (Eds), FINEP/ PADCT/ CIAMB/ FAPERGS/ FEPAM, cap. 3.2.
Migliavacca D, Teixeira EC, Wiegand F, Machado ACM AND SANCHEZ J. 2005. Atmospheric precipitation and chemical composition of an urban site, Guaíba hydrographic Basin, Brazil. Atmos Environ 39: 1829-1844.

Migon C, Journel B and Nicolas E. 1996. Measurement of trace metal wet, dry and total atmospheric fluxes over the ligurian sea. Atmos Environ 31: 6889-6896.

Mouli PC, Mohan SV And Reddy SJ. 2005. Rainwater chemistry at a regional representative urban site: influence of terrestrial sources on ionic composition. Atmos Environ 39: 999-1008.

Pandey JS, Kumar R and Devotta S. 2005. Health risks of $\mathrm{NO}_{2}, \mathrm{SPM}$ and $\mathrm{SO}_{2}$ in Delphi (India). Atmos Environ 39: $6868-6874$.

Park SU, In HJ, KIn SW and LeE YH. 2000. Estimation of sulphur deposition in South Korea. Atmos Environ 34: 3259-3269.

Sanusi A, Wortham H, Millet M and Mirabel P. 1996. Chemical composition of rainwater in eastern France. Atmos Environ 30: 59-71.

Seinfeld JH ANd Pandis SN. 1998. Atmospheric Chemistry and Physics: from air pollution to climate change. J Wiley \& Sons, New York, N.Y., USA, 1309 p.

SPOKES LJ AND JICKELS TJ. 1995. Speciation of metals in the atmosphere. In: URE AM AND DAVIDSON CM (Eds), Chemical speciation in the environment, Chapman \& Hall.

StockWell WR, Krichner F, Kuhn M And Seefeld S. 1997. A new mecanisms for regional atmospheric chemistry modeling. J Geophys Res 102: 25847-15879.

SWAINE DJ AND GOODARZI F. 1995. Environmental aspects of trace elements in coal, Kluwer Academic Publishers, $312 \mathrm{p}$.

Zhu X, Prospero JM, Savoie DL, Millero FJ, Zika RG AND SAltZMan ES. 1993. Photoreduction of iron (III) in marine mineral aerosol solutions. J Geophys Res 98: 9039-9046.

Zunckel M, SAIZAR C AND ZARAUZ J. 2003. Rainwater composition in Northeast Uruguay. Atmos Environ 37: $1601-1611$. 